\title{
A CONCEPTUAL APPROACH TO THE -ING CONSTRUCTION: ASPECTS OF RADIALITY AND SUBJECTIFICATION
}

\author{
Sandra Almeida ${ }^{1^{*}}$ \\ Iván Ulloa ${ }^{1^{* *}}$ \\ ${ }^{1}$ Universidade Federal de Juiz de Fora, Juiz de Fora, MG, Brasil
}

\begin{abstract}
The -ING construction has a number of uses in the English language, and teaching it to speakers of other languages poses some challenges, as learners tend to interpret the construction as a verbal one, in the progressive aspect, which is only one part of the picture. Bearing this in mind, we have developed a corpus-based research into the form-meaning/function pairing (Goldberg, 1995, 2006) of the construction, relying on Construction Grammar (Kay, Fillmore; 1999; Goldberg, 1995, 2006) and Cognitive Grammar (Langacker, 1987, 1990, 1991, 2008), apart from a semantic approach to the -ING construction (Wierzbicka, 1988), essential for describing the -ING construction from a conceptual perspective within the wide-ranging scope of Cognitive Linguistics (Geeraerts, 2006), which also included Prototype Theory (Rosch, 1973) and Radial Categories (Brugman, 1981; Lakoff, 1987). In regard to methodology, we have taken both a quantitative and qualitative approach to data (Cook; Reichardt, 1979; Richardson, 1985; Creswell, 2010) compiled from an English/Spanish parallel corpus of 1199 verbal ING occurrences. Our main hypothesis is that the -ING construction, in its verbal function, is more central or prototypical (Rosch, 1973; Brugman, 1981; Lakoff, 1987; Langacker, 2008) in respect to its conceptual network and its other functions, namely nominal, adjectival and adverbial. These functions, in turn, exhibit a more peripheral role and are linked to the verbal function through metaphorical extension relationships (Goldberg, $1995,2006)$. By performing a corpus-based analysis of the data (BerberSardinha, 2002, 2004) we finally argue that there is a radial organisation (Brugman, 1981; Lakoff, 1987) for the -ING construction, which goes from a more concrete level, being this more situated or grounded and thus more objectified (as a "here and now process"), until it gets to a more abstract level, therefore, less situated and more subjectified (taken as a "thing").

Keywords: Construction Grammar; Cognitive Grammar; Radiality; Subjectification; -ING Construcion.
\end{abstract}

\footnotetext{
* Professora Adjunta do curso de Letras-Bacharelado em Tradução e do Programa de Pós-graduação em Linguística da UFJF. Possui interessa por pesquisas na área de Linguística Cognitiva, especificamente sobre Gramática Cognitiva e Gramática das Construções, em suas interfaces tanto com o ensino de língua estrangeira quanto de tradução. E-mail: sandra.sf@gmail.com. ORCID: https://orcid.org/0000-0002-1311-7510.

** Professor de Língua Inglesa e de Tradução pela UABC (México) e Mestre em Linguística pela UFJF. Possui interessa por pesquisas na área de Linguística Cognitiva, especificamente sobre Gramática Cognitiva e Gramática das Construções, em suas interfaces tanto com o ensino de língua estrangeira quanto de tradução. E-mail: idavis@uabc.edu.mx. ORCID: https://orcid.org/0000-0002-5152-0722.
} 


\section{Introduction}

Teaching English as a foreign language poses a number of challenges to the English as a Foreign Language (EFL) teacher. One of these is the teaching of the -ING construction, especially to students of romance languages, such as Spanish and Portuguese. The most prototypical (Rosch, 1973; Brugman, 1981; Lakoff, 1987) use of the construction, i.e. the verbal function in its progressive aspect, is often taught in the first year of language teaching, whereas the other uses, namely the adverbial, adjectival and nominal uses, tend to be taught later in the language courses (Richards; Renandya, 2002). Nonetheless, students tend to extend the prototypical verbal progressive meaning to the other functions as well, thus often producing incomprehensible discourse.

While we recognise that all these functions of the construction are related through a constructional network of both semantic and syntactic functions (Wierzbicka, 1988; Kay \& Fillmore, 1999; Goldberg, 1995, 2006; Langacker, 2008), we argue that such differentiation in function and use relies on a more objective or subjective construal (Talmy, 2000; Langacker, 1987, 1990, 1991, 2008) of the scene described, which tends to be more grounded or less grounded (Langacker, 1990, 2008) on spatial and/or temporal deixis.

The main contribution of this paper is to propose a constructionist approach to the -ING construction which brings together its core functions in English in a close relation with other languages, such as Spanish, whose uses clearly resemble the ones found in the English language. While recognising the main contributions of both English and Spanish traditional grammars (see Eckersley \& Eckersley, 1960; Quirk \& Greenbaum, 1973; Leech \& Svartvik, 1975; Biber, Conrad \& Leech, 2002; Rae, 2010), we assume a constructionist view of the -ING construction, taking into account, at the same time, its cognitive and semantic aspects, trying to reach a gradient representation of the construction within its constructional network, which could ultimately be taken into consideration in further pedagogical applications.

This paper is organised in the following way: we first summarise the main views on the -ING construction, from traditional to more contemporary views, especially in regard to conceptual approaches (sections 1 and 2). We then focus on the main concepts which support our conceptual perspective on the subject, outlining our objectives and hypothesis against a number of data collected from an English/Spanish parallel corpus (Berber-Sardinha, 2002, 2004) (section 3). We then perform a corpus-based analysis, based on both quantitative and qualitative data (Cook; Reichardt, 1979; Richardson, 1985; Creswell, 2010) (section 4) and we finally draw some conclusions based on our findings.

\section{Towards a constructionist approach of the -ING construction}

Traditional grammars subsume the -ING construction under a number of tenses and aspects in regard to its verbal function, apart from its adverbial, 
adjectival, nominal and prepositional uses. In this paper, we will restrict our approach to the verbal, adverbial, adjectival and nominal uses of the construction, in accordance with our corpus data.

In more classic views (Eckersley \& Eckersley, 1960; Quirk \& Greenbaum, 1973; Leech \& Svartvik, 1975; Biber, Conrad \& Leech, 2002) grammarians primarily divide the -ING construction into participles and gerunds and derive their uses from this basic distinction. In this respect, Eckersley and Eckersley (1960), note that "whereas the participle is a verbal adjective, the gerund is a verbal noun" (p. 243). However, such distinction, though fundamental to our study, is not found in other traditional grammars (see Quirk \& Greenbaum (1973); Leech \& Svartik (1975); Biber, Conrad \& Leech (2002)), to mention but a few, in which the -ING is treated as a mere participle form.

From a semantic standpoint, Wierzbicka (1988) recognises that there is a "similarity between the two categories in their 'sameness of time' component" (Wierzbicka, 1988, p. 60). She points out that "gerundive complements can differ [...] from present participles and from finite -ING forms because they don't always refer to stretches of time" (Wierzbicka, 1988, p. 83). Instead, she argues, the gerund refers to momentary events while participial clauses imply "a vague simultaneity" of events. She further states that "whenever participial clauses refer to temporal semantic types (such as actions and processes) they imply sameness of time; when they refer to facts (a non-temporal category) simultaneity or otherwise is irrelevant to them" (Wierzbicka, 1988, p. 68). Again, such distinction will be fruitfully exploited in our approach to the construction, which will be ultimately analysed under a number of functions.

In a similar vein, Langacker (2008) discusses verb and noun schemas in terms of conceptualisation and categorisation. He argues that the difference between nouns and verbs is a matter of construal, i.e., the way a conceptualiser chooses to portray a given scene or speech event: while the verb expresses the process itself, the noun expresses the reification of such a process, thus approaching what Langacker calls "thing". Grammar categories, thus, are seen as a matter of profiling (Langacker, 2008) which is implied in conceptualisation, not as an intrinsic semantic property of the category per se.

In discussing the construal of verbs and nouns, Langacker points out that verbs can be perfective or imperfective, depending on their semantic properties and a number of other aspects related to the conceptualisation of the scene or speech event. For example, verbs like fall, break and learn are considered perfective, as they are bounded in time, i.e. they conceptualise a beginning and an end or even a change over time. Verbs like be, know and like, on the other hand, are imperfective, as they are unbounded in time, i. e. they tend to refer to more stable situations. Interestingly, Langacker notes that "English perfectives take the progressive but resist the simple present tense; imperfectives do the opposite" (p. 147).

In developing his concept of verb and noun schemas, Langacker (2008) discusses the verb schema in regard to the -ING construction, which he recognises as promoting two different types of scanning in describing an action or process: 
a sequential scanning or a summary scanning. The former is related to "mentally tracking an event as it unfolds through time, that is, scanning sequentially through it along the temporal axis"(p. 111), whereas in the latter "states are still accessed in their natural sequence, [but] they undergo summation: that is, they are mentally superimposed, resulting in their simultaneous activation" (p. 111). Finally, Langacker observes that "sequential scanning is equally applicable whether an event is observed, remembered or imagined" (p. 111).

Having all these arguments in mind, we assume that the -ING construction in its verbal progressive function is the most prototypical use of the present participle as it conceptualises a speech event, taking, as Langacker (2008, p. 155) argues, "an 'internal perspective' in this relationship" described, assigning the speech event the most concrete reading and thus being put onstage, on the ground (Langacker, 1987, 1990, 1991, 2008).

We will therefore assume, in this paper, that the more "grounded", the more situated a speech event is, including elements of temporal and spatial deixis, the more it invites a concrete, objective, sequential representation of the verbal process. The less "grounded" or situated a speech event is, the more it serves as a backgrounding strategy and relies on a mental, subjective construal of the event, reifying the verbal process in a summary scanning. In the next section we will discuss such objective/subjective representation of speech events in regard to the use of the -ING construction in our corpus data.

\section{A radial and subjectified view of the -ING construction}

When discussing how grammatical categories come to convey meaning, Langacker (2008) notes that "objects and actions, for instance, are respectively prototypical for the noun and verb categories" (p. 94). However, as he clearly points out, we cannot assume that such objectivist view of language suffices for assigning linguistic meaning to language structures. What he defends is that our cognitive capacity can construe a scene or speech event in different ways, thus producing different structures, or put differently, distinct constructions to express semantic content. These constructions can have a central, prototypical meaning, or, depending on a number of conceptual aspects, can convey a peripheral meaning as well.

The notion of prototypicality can be traced back to Rosch (1973) in her acclaimed study on how we conceptualise colours, then also being extended to forms, organisms and objects. Brugman (1981) and Lakoff (1987) have expanded this concept for other lexical as well as grammatical items, discussing how some members can exhibit more features of a given group, class or category, whereas others tend to convey fewer characteristics, thus being assigned a more peripheral position. The study presented by these authors relied on the radiality of the lexical item there, which, they argued, ranged from a more prototypical use, closely related to its more concrete, deictic use, such as in "There's Harry with the red jacket on", to an existential use, like in "There goes our last hope", to a 
narrative use, as in "There I was in the middle of the jungle". In our paper, we argue that the -ING has a more prototypical use, which coincides with the grounding (Langacker, 1987, 1990, 1991, 2006, 2008) of the speech event in its temporal and/or spatial deixis, as, we assume, the verbal progressive construction does: the processing time and the conceived time (Langacker, 2008) are superimposed. As the construction loses grounding and acquires a more adjacent role, as in backgrounding an action or event in relation to its more prominent (Langacker, $1987,1990,1991,2008)$ scene, it either develops adverbial, adjectival or nominal status. In doing so, we argue that the most prototypical, verbal progressive use or function has a more concrete reading, as it can be traced back in space and/ or time due to explicit reference to the ground. The less grounded it becomes, the more it relies on the conceptualiser's own perspective on the scene, the construal becoming more abstract and more subjectified, i. e., less objective, with less reference to the ground. Subjectification, in Langacker's (1990) terms, is an important type of semantic extension which involves the way a certain speech event is conceptualised. In his view, the semantic value of an expression is determined by a number of elements from the scene conveyed by a construction, such as the level of specificity, background, expectations, prominence among entities and the perspective taken on the scene.

In this paper, we argue that the -ING construction organises itself radially from a more concrete, objective construal, with a profiled relationship being put onstage, to a more abstract and subjectified configuration, with the conceptualizer construing the speech event offstage in a more subjective fashion.

In the next sections we will present the methodology followed for the study and the corpus-based analysis undertaken.

\section{Methodology}

Bearing the -ING construction in mind, we selected a collection of detective short stories in order to map exemplars of this construction. The corpus (BerberSardinha, 2002, 2004) chosen was The Adventures of Sherlock Holmes, written by Arthur Conan Doyle and published in 1982, which was obtained from $w w w$. mansioningles.com, a website that provides various books of different genres, as well as their translations into the Spanish language. The Spanish version included in our corpus data was translated by Juan Antonio Molina Foix and published in 2012 by the publishing house Valdemar.

Since our study hypothesizes that the verbal function is the most prototypical one, from which other functions evolve (Goldberg, 1995, 2006), we restricted our present data to the verbal occurrences of the construction, and ultimately propose a radial organisation for the syntactic patterns, i.e., the verbal ones, found in our data. We compiled 1199 occurrences of the verbal -ING construction and listed the Spanish translations for these occurrences. In order to do that, both the original and the translated versions of the book were manually aligned, thus forming an English/Spanish parallel corpus on which the present analysis is based. 
We thus argue that the -ING construction, in its verbal function, is more central or prototypical (Rosch, 1973; Brugman, 1981; Lakoff, 1987; Langacker, 2008) in respect to its conceptual network and its other functions, namely nominal, adjectival and prepositional. These functions, in turn, present a more peripheral role and are linked to the verbal function through metaphorical extension relationships (Goldberg, 1995, 2006). These relationships, we argue, establish a gradient between these functions, going from the most or more grounded level up to the most abstract, subjectified level (Langacker, 1990).

In the next section we will look more carefully into these different functions, outlining both a quantitative and a qualitative analysis of our corpus data.

\section{Corpus-based data analysis}

Based on the occurrences we have selected from our English/Spanish parallel corpus, we will present the first results we have reached from our data compilation.

\subsection{A quantitative approach to corpus data}

According to our data, the -ING construction was more frequent in the participial form, with $73.65 \%$ of the cases, as can be seen in Table 1 below. The gerundive form, on the other hand, accounted for $26.35 \%$ of the total. Considering the corpus for the study, which comprised a number of short stories classified into detective stories, having the narrator as one of the profiled participants in the scene or just an implicit viewer - but in both cases the main conceptualiser of the speech events narrated- can possibly explain the higher frequency for the -ING construction related to its participle form, as this is assumed to be the most prototypical function, being allusive to progressiveness, continuity or repetition. The gerundive construction, on the other hand, being more related to the reification and nominalization of actions, is noticeably less frequent, as it assumes a more peripheral sense.

Table 1. Overall Categorization of the -ING Construction

\begin{tabular}{|l|l|l|}
\hline Type of Construction & $\begin{array}{l}\text { Number of } \\
\text { Occurrences }\end{array}$ & $\begin{array}{l}\text { Frequency of } \\
\text { Occurrences }\end{array}$ \\
\hline Participle Construction & 883 & $73.65 \%$ \\
\hline Gerund Construction & 316 & $26.35 \%$ \\
\hline TOTAL & 1199 & $100 \%$ \\
\hline
\end{tabular}

In detailing the basic distinction between participles and gerunds, we have found at least three key functions for the participial -ING construction in our corpus data, as can be seen from Table 2 below. The adverbial function accounted 
for nearly half the occurrences, with $47.90 \%$ of the cases. This function of the -ING construction signals causal, manner or temporal meaning for the events that take place in the narrative, often assuming the role of providing background information for the main event or action being profiled or focused on. The first example is: At the church door, however, they separated, he driving back to the Temple, and she to her own house. Two participants are directly involved in the action of driving, which shows progressiveness and simultaneity, thus alluding to a temporal property of the participial - ING construction (Wierzbicka, 1988).

The second most frequent function, the progressive one, accounted for $31.60 \%$ of the cases. Assumed as the most prototypical construction of the -ING network, as it is the most grounded on either temporal and spatial deixis, making processing time and conceived time (Langacker, 2008) overlap, the example, "I am following you closely," I answered., shows that the action being performed (at a conceived time) and the moment of speaking (processing time) coincide, profiling a scene more situated on the ground, since it objectively focuses on the action being performed in a "here and now" domain.

The third type of participial function, the adjectival one, accounted for $20.50 \%$ of the cases. Under this use, the verbal progressive construction serves an adjectival, descriptive function rather than focusing on the very action. In other words, the action itself is not prominent or salient in the scene. In the example There was a group of shabbily dressed men smoking, the -ING construction serves to portray the participants involved, focusing on certain elements of the scene, in this case, the characters, making them more prominent, and underfocuses the action itself, expressed in what they are doing.

Table 2. Categorisation of the -ING Participle Construction

\begin{tabular}{|l|l|l|}
\hline Type of Participial Construction & $\begin{array}{l}\text { Number of } \\
\text { Occurrences }\end{array}$ & $\begin{array}{l}\text { Frequency of } \\
\text { Occurrences }\end{array}$ \\
\hline $\begin{array}{l}\text { Adverbial } \\
\text { Construction }\end{array}$ & 423 & $47.90 \%$ \\
\hline Verbal Progressive Construction & 279 & $31.60 \%$ \\
\hline $\begin{array}{l}\text { Adjectival } \\
\text { Construction }\end{array}$ & 181 & $20.50 \%$ \\
\hline TOTAL & $\mathbf{8 8 3}$ & $\mathbf{1 0 0 \%}$ \\
\hline
\end{tabular}

In regard to the gerundive -ING construction, the nominal function was the most frequent, with $76.90 \%$ of the cases, as can be seen from Table 3. As Langacker (2008) points out, the gerund often denotes the conceptualisation of a verb process being reified, thus belonging to an abstract domain which is not directly accessed unless via mental, subjective scanning by the conceptualiser, either alluding to future, routinary or simply nonprocessual actions. In the example When an actor I had, of course, learned all the secrets of making up [...]. the action of making up has probably gained the value of a routinary action through time; in other words, it exhibits more features of an action conceived as a "thing" (Langacker, 2008). 
The adverbial function, which we argue, again, serves as background information to the event profiled, whether establishing a temporal or causal link between them, accounted for only $23.10 \%$ of the cases, as in I noted, in passing, that she had written a note before leaving home but after being fully dressed. Here we notice a clear temporal value of the construction, which could be paraphrased as "I noted, when I passed", modifying the main action. Also, in the case of the events introduced by connectors like before and after, the sequence of actions is taken in a holistic way, i.e. in summary scanning.

Table 3. Categorisation of the -ING Gerund Construction

\begin{tabular}{|l|l|l|}
\hline Type of Gerund Construction & $\begin{array}{l}\text { Number of } \\
\text { Occurrences }\end{array}$ & $\begin{array}{l}\text { Frequency of } \\
\text { Occurrences }\end{array}$ \\
\hline $\begin{array}{l}\text { Nominal } \\
\text { Construction }\end{array}$ & 243 & $76.90 \%$ \\
\hline $\begin{array}{l}\text { Adverbial } \\
\text { Construction }\end{array}$ & 73 & $23.10 \%$ \\
\hline TOTAL & 316 & $100 \%$ \\
\hline
\end{tabular}

As can be seen from Table 4 below, the most frequent results for the -ING construction in regard to its Spanish translated forms are, respectively, the gerund, the infinitive, the imperfect and the noun. The other constructions were much less frequent and will not be discussed here.

Table 4: Quantitative Results of the -ING Construction in the English/Spanish Parallel Corpus

\begin{tabular}{|l|l|l|}
\hline Original => Translation & $\begin{array}{l}\text { Number of } \\
\text { Occurrences }\end{array}$ & $\begin{array}{l}\text { Frequency of } \\
\text { Occurrences }\end{array}$ \\
\hline ING=> Gerund & 463 & $38.60 \%$ \\
\hline ING=>Infinitive & 274 & $22.80 \%$ \\
\hline ING=>Imperfect & 158 & $13.20 \%$ \\
\hline ING=>Noun & 69 & $5.70 \%$ \\
\hline ING=> Past & 55 & $4.60 \%$ \\
\hline ING=>Present & 50 & $4.20 \%$ \\
\hline ING=> Past Participle & 42 & $3.50 \%$ \\
\hline ING=> & 27 & $2.20 \%$ \\
\hline ING=>Subjunctive & 26 & $2.20 \%$ \\
\hline ING=>Adjective & 14 & $1.20 \%$ \\
\hline ING=>Antepresente & 8 & $0.70 \%$ \\
\hline ING=> Future & 7 & $0.60 \%$ \\
\hline ING=>Antecopretérito & 4 & $0.30 \%$ \\
\hline ING=> Pospretérito & 1 & $0.10 \%$ \\
\hline ING=> Antefuturo & 1 & $0.10 \%$ \\
\hline TOTAL & 1199 & $100 \%$ \\
\hline
\end{tabular}


In the next section, we will approach these cases in our qualitative analysis, arguing for a most concrete/least concrete gradient organisation of these constructions in accordance with the conceptual import they exhibit in face of the discussion we have developed so far for the -ING construction in English.

\subsection{A qualitative approach to corpus data}

As our main objective is to observe and analyse the behavior of the -ING construction in the English/Spanish language pair, we have selected the most frequent constructions in our English/Spanish parallel corpus. We will discuss some of these patterns and ultimately propose a constructional network for the -ING construction based on the semantic extensions (Goldberg, 1995, 2006) it conveys.

The first example analysed relies on the progressive function of the participial -ING construction, assumed as the most prototypical:

1. The -ING Participle Construction as Present Progressive Translated as Gerundive Periphrasis (estar + gerund)

Original: "What on earth can be the matter with him?" I asked. "He is looking up at the numbers of the houses." "I believe that he is coming here," said Holmes, rubbing his hands. (p. 126)

Translation: - ¿Qué demonios puede pasarle? —pregunté-. Está mirando los números de las casas. —Me parece que viene aquí —dijo Holmes, frotándose las manos. (p. 241)

As we have argued, this is the most prototypical function of the construction as it is more situated or more "grounded" in the "here and now" (Langacker, 2008), i.e. in temporal and/or spatial deixis. Having Watson as the narrator, who is also a character and conceptualises the scene from his perspective, he observes the scene and describes it as he watches it. This interpretation is coherent with the function traditional English grammar assigns to this tense as describing "an action which began in the past and will terminate in the future, but which at the moment of speaking is incomplete and is still continuing" (Eckersley \& Eckersley, 1960, p. 168). In the same way, we argue that this more grounded, more concrete function of the -ING construction is translated into an -NDO construction in Spanish, in reference to a gerundive construction. Such construction describes an action on course (Rae, 2010), thus perfectly matching the function assigned to the -ING construction, in the original text, as both construe a speech event as exhibiting progressiveness or continuity over a period of (present) time.

The second case relies on the adverbial function of the construction, as we will see below. 
2. The -ING Participle Construction in Two or More Linked Actions Translated as a Gerund (-NDO)

Original: "The circumstances are of great delicacy, and every precaution has to be taken to quench what might grow to be an immense scandal and seriously compromise one of the reigning families of Europe. To speak plainly, the matter implicates the great House of Ormstein, hereditary kings of Bohemia." "I was also aware of that," murmured Holmes, settling himself down in his armchair and closing his eyes. (p. 4)

Translation: - Trátase de circunstancias sumamente delicadas, y es preciso tomar toda clase de precauciones para ahogar lo que pudiera llegar a ser un escándalo inmenso y comprometer seriamente a una de las familias reinantes de Europa. Hablando claro, está implicada en este asunto la gran casa de los Ormstein, reyes hereditarios de Bohemia. - También lo sabía - murmuró Holmes arrellanándose en su sillón, y cerrando los ojos. (p. 9)

In this example, Watson, the narrator, is close to Holmes, and conceptualises the scene objectively, placing both participants onstage, on the ground. The use of the -ING construction as a link between two or more actions, as Eckersley \& Eckersley (1960) point out, functions as a connection between two actions that are happening at about the same time. In the same fashion, Wierzbicka (1988) relates this construction to simultaneity, but she also argues that there exists a notion of continuity; which means that the three actions (murmured, settling down, and closing), also signal a certain duration as they convey a sequence of actions, inheriting duration not from the verbs themselves, but through context.

The third case regards the adjectival function that the -ING construction assumes within its constructional network of form-meaning pairings:

3. The -ING Participle Construction with Adjectival Function Translated as Present

Original: "Pray what steps did you take when you found the card upon the door?" "I was staggered, sir. I did not know what to do. Then I called at the offices round, but none of them seemed to know anything about it. Finally, I went to the landlord, who is an accountant living on the ground-floor, and I asked him if he could tell me what had become of the Red-headed League." (p. 20)

Translation: Vamos a ver, ¿qué pasos dio usted al encontrarse con ese letrero en la puerta? - Me dejó de una pieza, señor. No sabía qué hacer. Entré en las oficinas de al lado, pero nadie sabía nada. Por último, me dirigí al dueño de la casa, que es contador y vive en la planta baja, y le pregunté si podía darme alguna noticia sobre lo ocurrido a la Liga de los Pelirrojos. (p. 39)

In this example, the -ING construction has an adjectival function, since the participle, although following the noun, works as a modifier and describes 
the noun itself, in this case the accountant, with a verbal quality (Eckersley \& Eckersley, 1960). Thus, it can be argued that the action is not happening at the moment of speaking. This conceptualisation refers to a more permanent situation, which is living in a certain place. In this case, however, the construction serves to identify a participant of the speech event by placing focus or giving prominence to him in the conceptualisation, with the -ING construction assuming a more abstract sense, more grounded on the speaker's perspective, thus being more subjectified (Langacker, 1990). This probably explains the choice of the present simple in the translated version, since that idea converges with what Rae (2010) states about the Descriptive Present in Spanish, which refers to stable situations that permit to describe persons or things. In other words, the construction in Spanish also takes a more abstract reading, as it primarily profiles the character himself, rather than the action of his living, on the ground.

The next example relies on the gerundive -ING form, thus emphasizing the reification and abstractness of the construction:

\section{The -ING Gerund Construction Translated as Infinitive}

In the example below, as the carriage enters the street, Watson, the narrator and one of the conceptualisers, describes the scene in the following way:

Original: As it pulled up, one of the loafing men at the corner dashed forward to open the door in the hope of earning a copper, but was elbowed away by another loafer, who had rushed up with the same intention. (p. 11)

Translation: Uno de los vagabundos echó a correr para abrir la puerta del coche y ganarse de ese modo una moneda, pero otro, que se había lanzado a hacer lo propio, lo aparto violentamente. (p. 20)

In this scene, Watson, the narrator and conceptualizer, remains offstage and conceives the scene more subjectively, as a witness of a situation in which two other people are profiled; in this case, two loafing men. The perspective of Watson is relevant in order to describe the scene and at the same time "ground" the scene as a sequence of events. With respect to the -ING construction, we consider the action of earning in an abstract fashion. As it denotes an expectation, it is conceptualized in the form of the verb hope, indicating a future expectation about something to take place, which is not fulfilled.

This goes along with what Wierzbicka (1988) argues about the gerunds, in this case earning, which receives a 'head noun', one of possibility. In regard to the Spanish translation, we also argue that the infinitive denotes an action that implies abstraction, as it is a potential, but not a real outcome. We can also mention the use of the preposition para (for), whose "more characteristic sense is the one of purpose" (Rae, 2010, p. 569; my own translation). In the example, the infinitive of purpose construction is conceived in a cause (abrir la puerta)-effect (ganarse de ese modo una moneda) relationship. 
We finally present our -ING gerund construction in what we assume to be the most peripheral function of the construction, i.e. its nominal function:

5. The -ING Gerund construction Translated as a Noun

Watson describes the way Holmes keeps record of his clients, what he calls his "index". Watson profiles these records as a "system", which "for many years he [Holmes] had adopted", turning the -ING construction into a routinary activity, which is not taking place at the moment of speaking, but is conceptualised in a subjectified, abstract way, assuming what Langacker (2008, p. 111) calls "summary scanning", i.e., the action is reified and approaches nominalization:

Original: "The facts are briefly these: Some five years ago, during a lengthy visit to Warsaw, I made the acquaintance of the well-known adventuress, Irene Adler. The name is no doubt familiar to you." "Kindly look her up in my index, Doctor," murmured Holmes without opening his eyes. For many years he had adopted a system of docketing all paragraphs concerning men and things, so that it was difficult to name a subject or a person on which he could not at once furnish information. (p. 5)

Translation: - He aquí los hechos, brevemente expuestos: Hará unos cinco años, y en el transcurso de una larga estancia mía en Varsovia, conocí a la célebre aventurera Irene Adler. Con seguridad que ese nombre le será familiar a usted. Doctor, tenga la amabilidad de buscarla en el índice - murmuró Holmes sin abrir los ojos. Venía haciendo extractos de párrafos referentes a personas y cosas, Y era difícil tocar un tema o hablar de alguien sin que él pudiera suministrar en el acto algún dato sobre los mismos. (p. 9)

Here, the conceptualizer, Watson, profiles a scene of a process that had been occurring for a long time until the time of speaking. In terms of conceptualizing that process, which seems to be the most prominent in the scene, the -ING takes the role of what Wierzbicka (1988) denominates as a head noun, giving to 'docketing' the semantic role of a process, but situating that -ING construction in an even more abstract domain, as such process is reified, subjectively construed as a system by the conceptualizer. The noun construction, as seen in the Spanish translation, fits perfectly well into Langacker's (2008) proposal for a noun schema, i.e. a reified process approaching a 'thing. So, picking the noun extractos as an option converges with what Rae (2010) says about the noun, implying that it is allusive to a happening or a process, which is extraer, taken as in a holistic, summarised scanning.

In the next section, we will summarise the findings so far and present a proposal for the -ING form-meaning pairings which subsumes the functions analysed in our corpus data. 


\subsection{A proposal for a radial organisation}

By taking a concrete-to-abstract gradient to the -ING construction, we assume the Progressive Function as the conceptualisation of an action that is happening (conceived time) at the moment of speaking (processing time), making the scene, from the conceptualiser's perspective, more concrete and also more situated on the "ground" (Langacker, 1987, 1990, 1991, 2008). We then have the Adverbial Function, which, being a verb modifier, attains an adjacent role in conceptualising the scene, being, thus, underfocused or unprofiled. This function, we argue, nicely establishes the boundary between the inherently verbal function in its progressive use, which is profiled onto the ground, and the ones gaining even more adjacent or unprofiled (Langacker, 1987, 1991,2008) roles in comparison to the Adverbial Function, such as the Adjectival Function and the Nominal Function. These also tend to undertake more abstract, subjectified construals, relying more on the conceptualiser's mental scanning of the scene through his/her own perspective (Langacker, 1987, 1990, 1991, 2008).

We thus present the following diagram that would summarise our proposal for the -ING construction in terms of conceptualisation of speech events:

Figure 1. Radial Organisation of the -ING Construction

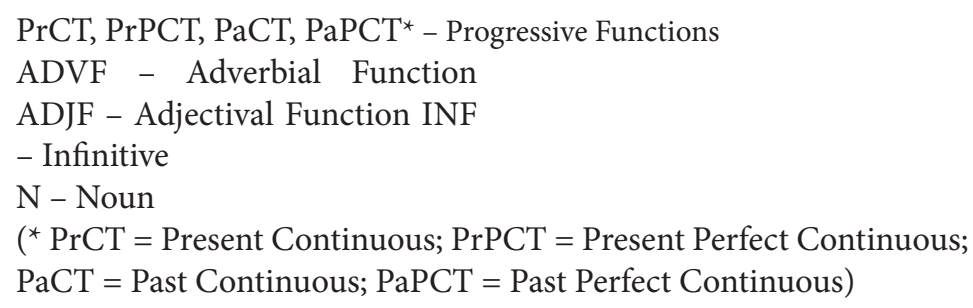

\section{Conclusions}

In this paper we carried out a conceptual approach to the behavior of the -ING construction in regard to its different form-meaning/function pairings (Goldberg, 1995, 2006), under the broader scope of Cognitive Linguistics (Brugman, 1981; Geeraerts, 2006; Lakoff, 1987; Langacker, 2008; Rosch, 1973; Wierzbicka, 1988), chiefly in regard to Prototype Theory and Radial Categories, apart from the contributions of Cognitive Grammar (Langacker, 1987, 1990, 1991, 2008), Construction Grammar (Kay \& Fillmore, 1999; Goldberg, 1995, 2006), as well as traditional grammars (Eckersley \& Eckersley, 
1960; Quirk \& Greenbaum, 1973; Leech \& Svartvik, 1975; Biber, Conrad \& Leech, 2002; Rae, 2010).

We developed a corpus-based research from the compilation of an English/ Spanish parallel corpus (Berber-Sardinha, 2002, 2004) of the work The Adventures of Sherlock Holmes, by Arthur Conan Doyle, concentrating our quantitative and qualitative analyses (Cook; Reichardt, 1979; Richardson, 1985; Creswell, 2010) on the verbal -ING construction under a number of functions.

The verbal construction was assumed to be more central or prototypical (Rosch, 1973; Brugman, 1981; Lakoff, 1987; Langacker, 2008), as it is more grounded on temporal and/or spatial deixis, thus being more objectively portrayed in a sequential scanning (as a "here and now process"), stretching into metaphorical extensions (Goldberg, 1995, 2006), more grounded on the conceptualiser's subjetified construal of the scene in a summary scanning (taken as a "thing") and assuming adverbial, adjectival or nominal functions (Langacker, 2008; Wierzbicka, 1988).

In regard to the Spanish language, the most frequent constructional corresponding patterns were the gerund, the infinitive, the imperfect and the noun. As well as the English constructions, they exhibited progressiveness, duration, repetition and simultaneity, also reaching nonprocessual notions that supported our analysis in terms of a gradient of concreteness/abstractness that contributed to the outline of a radial network of the construction.

Based on the results from both the quantitative and qualitative analyses, we outlined a radial network proposal for the construction which ranged from the most prototypical meaning of the -ING construction: the progressiveness, exhibiting features of being conceived in a more concrete domain, up to reaching nonprocessual uses, which are conceived in a more abstract domain.

\section{References}

BERBER-SARDINHA, T. (2002). Corpora eletrônicos na pesquisa em tradução. Cadernos de Tradução IX, Tradução e Corpora. Florianópolis: UFSC/NUT, vol.1, p. 15-59.

BERBER-SARDINHA, T. (2004). Linguística de corpus. Barueri: Manole.

BIBER, D.; CONRAD, S.; LEECH, G. (2002). Longman Student Grammar of Spoken and Written English. Harlow, Essex, England: Pearson Education Limited.

BRUGMAN, C. (1981) The Story of Over. MA Thesis, University of California, Berkeley.

COOK, T. D.; REICHARDT, C. S. (ed.). (1979). Qualitative and Quantitative Methods in Evaluation. Londres: Sage.

CRESWELL, J. W. (2010). Projeto de Pesquisa: Método Quantitativo, Qualitativo e Misto. São Paulo: Bookman Companhia Editora.

ECKERSLEY, C. E. \& ECKERSLEY, J. M. (1960). A Comprehensive English Grammar. Harlow: Longman.

GEERAERTS, D. (ed.) (2006). Cognitive Linguistics: Basic Readings. Berlin: Mouton de Gruyter (The Hague). 
GOLDBERG, A. (1995). Constructions: A Construction Grammar Approach to Argument Structure. Chicago: University of Chicago Press.

GOLDBERG, A. (2006). Constructions at Work: The Nature of Generalization in Language. New York: OUP.

KAY, P. \& FILLMORE, C. J. (1999). Grammatical Constructions and Linguistic Generalizations: the what's X doing Y? construction. Language 75, p. 1-34.

LAKOFF, G. (1987). Women, Fire and Dangerous Things. Chicago: The University of Chicago Press.

LANGACKER, R. (1987). Foundations of Cognitive Grammar. v. 1: Theoretical Prerequisites. Stanford: Stanford University Press, p. 29-67.

LANGACKER, R. (1990). Subjectification. In: Cognitive Linguistics 1-1, p. 5-38.

LANGACKER, R. (1991). Foundations of Cognitive Grammar. v. 2. Descriptive Applications. Stanford: Stanford University Press.

LANGACKER, R. Cognitive Grammar. In: GEERAERTS, D. (ed.). (2006). Cognitive Linguistics: Basic Readings. Berlin: Mouton de Gruyter (The Hague).

LANGACKER, R. (2008). Cognitive Grammar: A Basic Introduction. New York: Oxford University Press.

LEECH, G. \& SVARTVIK, J. (1975). A Communicative Grammar of English. London: Longman.

QUIRK, R. \& GREENBAUM, S. (1973). A University Grammar of English. London: Longman.

RAE. (2010). Nueva gramática de la lengua española. Madrid: Real Academia Española; Asociación de Academias de la Lengua Española.

RICHARDSON, R. J. (1985). Pesquisa Social: métodos e técnicas. São Paulo: Atlas.

RICHARDS, J. C.; RENANDYA, W.A. (2002). Methodology in language teaching: an anthology for current practice. Cambridge: Cambridge University Press.

ROSCH, E. (1973). On the Internal Structure of Perceptual and Semantic Categories. In: MOORE, T. (ed.). Cognitive Development and the Acquisition of Language. New York: Academic Press, p. 11-144.

TALMY, Leonard. (2000). Toward a Cognitive Semantics: Concept Structuring Systems, Volume 1, The MIT Press.

WIERZBICKA, A. (1988). The semantics of grammar. Amsterdam/Philadelphia: John Benjamins. 